\title{
SOIL CARBON AND NITROGEN STOCKS IN TRADITIONAL AGRICULTURAL AND AGROFORESTRY SYSTEMS IN THE SEMIARID REGION OF BRAZIL ${ }^{(1)}$
}

\author{
José Augusto Amorim Silva do Sacramento ${ }^{(2)}$, Ana Caroline de Moraes Araújo ${ }^{(3)}$, Maria \\ Eugenia Ortiz Escobar ${ }^{(4)}$, Francisco Alisson da Silva Xavier ${ }^{(5)}$, Ana Clara Rodrigues \\ Cavalcante $^{(6)}$ \& Teógenes Senna de Oliveira ${ }^{(7)}$
}

\begin{abstract}
SUMMARY
In the semiarid region of Brazil, inadequate management of cropping systems and low plant biomass production can contribute to reduce soil carbon (C) and nitrogen ( $N$ ) stocks; therefore, management systems that preserve $C$ and $N$ must be adopted. This study aimed to evaluate the changes in soil $\mathrm{C}$ and $\mathbf{N}$ stocks that were promoted by agroforestry (agrosilvopastoral and silvopastoral) and traditional agricultural systems (slash-and-burn clearing and cultivation for two and three years) and to compare these systems with the natural Caatinga vegetation after 13 years of cultivation. The experiment was carried out on a typical Ortic Chromic Luvisol in the municipality of Sobral, Ceará, Brazil. Soil samples were collected (layers 0-6, 6-12, 12-20, 20-40 and 40-60 cm) with four replications. The plain, convex and concave landforms in each study situation were analyzed, and the total organic $\mathrm{C}$, total $\mathrm{N}$ and densities of the soil samples were assessed. The silvopastoral system promoted the greatest long-term reductions in $\mathrm{C}$ and $\mathrm{N}$ stocks, while the agrosilvopastoral system promoted the smallest losses and therefore represents a sustainable alternative for soil $\mathrm{C}$ and $\mathrm{N}$ sequestration in these semiarid conditions. The traditional agricultural system produced reductions of 58.87 and $9.57 \mathrm{Mg} \mathrm{ha}^{-1}$
\end{abstract}

(1) Part of Master degree dissertation of the first author submitted to the Federal University of Ceará, UFC. Received for publication in August 24, 2012 and approved in March 26, 2013.

(2) Doctoral student of Federal University of Recôncavo da Bahia, UFRB. Rua Rui Barbosa, 710. CEP 44.380-000 Cruz das Almas (BA), Brazil. E-mail: jassacramento@yahoo.com.br

${ }^{(3)}$ Master student of Federal University of Ceará - UFC. Av. Mister Hull, s/n, Campus do Pici, Bloco 807. CEP 60440-554 Fortaleza (CE), Brazil. E-mail: carolsinha04@bol.com.br

(4) Professor of Soil Science Department, Federal University of Ceará - UFC. E-mail: mariaeugenia@ufc.br

(5) Researcher, Embrapa Mandioca e Fruticultura. Rua Embrapa, s/n. CEP 44380-00 Cruz das Almas (BA), Brazil. E-mail: alisson.xavier@embrapa.br

(6) Researcher, Embrapa Caprinos e Ovinos. Estrada Sobral-Groaíras km 4, Caixa Postal D10. CEP 62011-970 Sobral (CE), Brazil. E-mail: ana.clara@embrapa.br

(7) Professor, Soil Science Department, Federal University of Viçosa (UFV). Av P.H. Rolfs s/n. CEP 36570-00 Viçosa (MG), Brazil. CNPq Fellowship. E-mail: teo@ufv.br 


\begin{abstract}
in the organic $\mathrm{C}$ and total $\mathrm{N}$ stocks, respectively, which suggests that this system is inadequate for these semiarid conditions. The organic $C$ stocks were largest in the concave landform in the agrosilvopastoral system and in the plain landform in the silvopastoral system, while the total $N$ values were highest in the concave landform in the native, agrosilvopastoral and silvopastoral systems.
\end{abstract}

Index terms: carbon sequestration, conservation management, shifting cultivation.

\title{
RESUMO: ESTOQUES DE CARBONO E NITROGÊNIO DO SOLO EM SISTEMAS AGRÍCOLAS TRADICIONAL E AGROFLORESTAIS NO SEMIÁRIDO BRASILEIRO
}

\begin{abstract}
Na região semiárida, o manejo inadequado dos sistemas de cultivo, aliado à baixa produção de fitomassa, pode contribuir para reduzir os estoques de carbono $(C)$ e nitrogênio (N) do solo; portanto, a adoção de sistemas de manejo para a preservação desses elementos é necessária. Objetivou-se avaliar as alterações promovidas nos estoques de $C$ e $N$ do solo por sistemas agrícolas agroflorestais (agrossilvipastoril e silvipastoril) e tradicional (com derrubada da vegetação, queima e cultivo por dois-três anos), confrontando-os à vegetação natural de Caatinga, após 13 anos, em experimento instalado em um Luvissolo Crômico órtico típico, no município de Sobral, Ceará. Amostras de solo foram coletadas nas profundidades de 0-6, 612, 12-20, 20-40 e 40-60 cm, em quatro repetições, considerando os relevos plano, convexo e côncavo em cada situação de estudo, sendo determinados o $C$ orgânico total, o $N$ total e as densidades do solo. Entre os sistemas agroflorestais estudados, o silvipastoril, em longo prazo, promoveu as maiores reduções nos estoques de $C$ e $N$, enquanto o agrossilvipastoril as menores perdas, representando alternativa sustentável para o sequestro de $C$ e $N$ do solo nessas condições semiáridas. O sistema de cultivo tradicional apresentou reduções de 58,87 e 9,57 $\mathrm{Mg} \mathrm{ha}^{-1}$ dos estoques de Corgânico e $N$ total, respectivamente, indicando sua não adequação para as condições semiáridas brasileiras. Os relevos côncavo, no sistema agrossilvipastoril, e plano, no silvipastoril, apresentaram os maiores estoques de $C$ orgânico, enquanto para o $N$ total, a forma côncava apresentou os maiores valores na vegetação nativa, agrossilvipastoril e silvipastoril.
\end{abstract}

Termos de indexação: sequestro de carbono, manejo conservacionista, agricultura itinerante.

\section{INTRODUCTION}

In northeastern Brazil, in the State of Ceará, two million hectares are planted crop area, second only to the State of Bahia (Indicadores de Desenvolvimento Sustentável, 2010). Until today, agriculture in Ceará consisted mostly of extractivism (gatherer exploitation), with the use of indiscriminate slash-andburn practices and inadequate fallow periods, which has depleted the predominant natural vegetation (Caatinga). Moreover, the region is characterized by high temperatures, low rainfall, little weathered soils and low plant biomass production (Araújo Filho, 2002). Under these conditions, the inadequate management of cropping systems and low plant biomass production may effectively contribute to reductions in soil organic matter (SOM) stocks.

Soil organic matter is primarily regulated by the input and decomposition of organic residues (Maia et al., 2008). The main constituents of SOM are C (52$58 \%)$ and $\mathrm{N}(3.7-7 \%)$; the soil levels and pools of these elements vary according to the application rates of plant and animal residues and to the losses resulting from erosion and oxidation by soil microorganisms
(Souza et al., 2009). SOM is involved in the balance between the $\mathrm{C}$ and $\mathrm{N}$ cycles, and its content is stable in soils under native vegetation (Bortolon et al., 2009). When this balance is disrupted, the organic residue input is smaller relative to the output (Cerri et al., 2008).

The replacement of native vegetation with traditional agricultural systems has promoted changes in both the dynamics of organic residue inputs and in the decay rate and loss of these residues (Nunes et al., 2011). In traditional agricultural systems tillage is usually more intense, leading to erosive losses and increased microbial activity due to the greater exposure of organic residues to microorganisms and their enzymes (Maia et al., 2006; Souza et al., 2009). These conditions result in decreased levels of $\mathrm{C}$ and $\mathrm{N}$ and, consequently, increased C- $\mathrm{CO}_{2}$ emissions into the atmosphere and decreased $\mathrm{N}$ cycling (Sharma et al., 2005). Conversely, conservation systems that prioritize the organic residue input and reduced tillage, including no-tillage (Souza et al., 2009; Maia et al., 2010), agrosilvopastoral systems (Maia et al., 2007; Aguiar et al., 2010), silvopastoral systems (Maia et al., 2006; Tonucci et al., 2011), and organic farming (Xavier et al., 2006), have proved efficient in 
maintaining and sometimes raising the soil $\mathrm{C}$ and $\mathrm{N}$ levels (Maia et al., 2008).

In this context, agroforestry systems (AFSs) represent a key alternative, since an adequate tree management promotes an effective ground cover and contributes to the maintenance and control of soil moisture (Aguiar et al., 2010). Studies conducted in the semiarid region of Brazil addressed the impacts of AFSs on soil quality (Maia et al., 2006); nutrient redistribution (Nogueira et al., 2008); soil, water and nutrient losses by water erosion (Aguiar et al., 2010); $\mathrm{N}$ fractions (Maia et al., 2008); organic C reservoirs (Maia et al., 2007); and on soil physical quality (Silva et al., 2011). These studies indicated that AFSs may be viable and sustainable alternatives for soil and water use in this region.

An understanding of the organic matter dynamics in soils requires temporal studies, since changes in the soil organic matter and interactions that result from adopted management practices tend to appear gradually (Souza et al., 2009). In this context, this study assumes that in the long term, AFSs increase the total soil organic $\mathrm{C}$ and $\mathrm{N}$ stocks, evaluating the changes in total soil $\mathrm{C}$ and $\mathrm{N}$ stocks under agroforestry (silvopastoral and agrosilvopastoral) and traditional agricultural systems by comparing these systems to the natural vegetation of Caatinga, after 13 years of cultivation in a typical Ortic Chromic Luvisol, in the semiarid region of Ceará, Brazil.

\section{MATERIAL AND METHODS}

\section{Study area}

The experimental area Fazenda Crioula belongs to the Goat and Sheep Center of the Brazilian Agricultural Research Corporation (Centro Nacional de Pesquisa de Caprinos - Embrapa/CNPC) and is located in Sobral, Ceará, Brazil. This municipality is located in the semiarid region of Ceará $\left(3^{\circ} 41^{\prime} \mathrm{S}\right.$, $40^{\circ} 20^{\prime} \mathrm{W}$ ) at $70 \mathrm{~m}$ asl (Figure 1). The average annual temperature and rainfall are $27^{\circ} \mathrm{C}$ and $821.6 \mathrm{~mm}$ year $^{-1}$, respectively. The rainy season typically occurs from February to May (IPECE, 2005). The soils consist partly of typical Ortic Chromic Luvisol and partly of typical Ortic Haplic Luvisol (Aguiar et al., 2006), according to the soil classification by Embrapa (2006).

Since 1997, each AFS has been studied by Embrapa/CNPC, and each consisted of three integrated subareas that were primarily designed for agricultural and livestock production and natural vegetation preservation (Caatinga). These subareas are characterized by the following systems, listed in descending order of priority: agrosilvopastoral (AGP), silvopastoral (SILV) and natural vegetation (NV). In addition to these systems, the traditional system (TR), characterized by slash-and-burn clearing followed by cultivation for two to three years, was also evaluated in this study. The chemical and physical characterizations of the soil and descriptions of each system are shown in tables 1 and 2 , respectively.

\section{Soil sampling and analysis}

Disturbed soil samples and soil clods were collected in mini-trenches $(50 \times 50 \times 50 \mathrm{~cm})$ at depths of 0-6, 6$12,12-20,20-40$ and $40-60 \mathrm{~cm}$ from the plain, convex and concave landforms, according to Nogueira (2009). The samples were air-dried, and the disturbed soil samples were sieved $(2 \mathrm{~mm})$.

Total soil organic carbon (TOC) assessments were performed with a potassium dichromate solution in acidic medium and with an external heat source (Yeomans \& Bremner, 1988). Total nitrogen (TN) was quantified by sulfuric acid digestion (Bremner, 1996).

Soil density was assessed by the resin-coated clod technique (Embrapa, 1997), due to the excessive stoniness and shallow soil depth $(60-80 \mathrm{~cm}$ deep) (Aguiar et al., 2010) of the areas.

The soil $\mathrm{C}$ and $\mathrm{N}$ stocks were calculated by multiplying the soil density, sampled depths and the soil TOC and TN contents according to the following equation: $\mathrm{E}=\mathrm{d} \times \mathrm{h} \times(\mathrm{TOC}$ or $\mathrm{TN}) / 10$, in which $\mathrm{E}$ is the TOC or TN stock ( $\left.\mathrm{Mg} \mathrm{ha}^{-1}\right), \mathrm{d}$ is the soil bulk density $\left(\mathrm{Mg} \mathrm{m}^{-3}\right)$, $\mathrm{h}$ is the sampled layer $(\mathrm{cm})$, TOC and TN are the total soil levels of organic $\mathrm{C}$ and $\mathrm{N}$ $\left(\mathrm{g} \mathrm{kg}^{-1}\right)$, respectively, and 10 is the unit converter.

\section{Statistical analyses}

The experimental design consisted of randomized blocks with split plots, each of which was replicated in quadruplicate. The treatments consisted of four areas (plots), three different landforms (subplots) and five soil depths (sub-subplots). Data related to the TOC and TN stocks were subjected to analysis of variance (ANOVA) to assess the effects of soil management systems and landforms at each depth and the differences between the depths within each soil tillage system. The means were compared by Tukey's test at $5 \%$ probability using ASSISTAT software, Version 7.6 beta (2011) (Silva \& Azevedo, 2009).

\section{RESULTS AND DISCUSSION}

\section{Soil total organic carbon levels and stocks}

The soil TOC levels were higher in the first two layers (0-6 and 6-12 cm) in all management systems studied and were significantly different from the TOC levels in the other layers (Figure 2). These results corroborated those reported by Maia et al. (2007) and Heinze et al. (2010), even in the case of the traditional agricultural system. The traditional soil use system tends to partly stabilize the levels of TOC and other elements at deeper depths, likely due in part to topsoil 
tillage (Rangel et al., 2007). The results of this study were compared with data reported by Maia et al. (2007) for the same layers and experimental area, in 2002; TOC contents of $34.8,22.3$ and $34.4 \mathrm{~g} \mathrm{~kg}^{-1}$ in $0-6 \mathrm{~cm}$ and TOC contents of $17.2,14.4$ and 23.1 in the $6-12$ cm layer were found in the SILV, AGP and TR systems, respectively. These data indicate respective losses of 23.2 and $59.6 \%$ in the SILV and TR systems, while a gain of $6.4 \%$ was observed in the $0-6 \mathrm{~cm}$ layer of the AGP system. The losses in the $6-12 \mathrm{~cm}$ layer

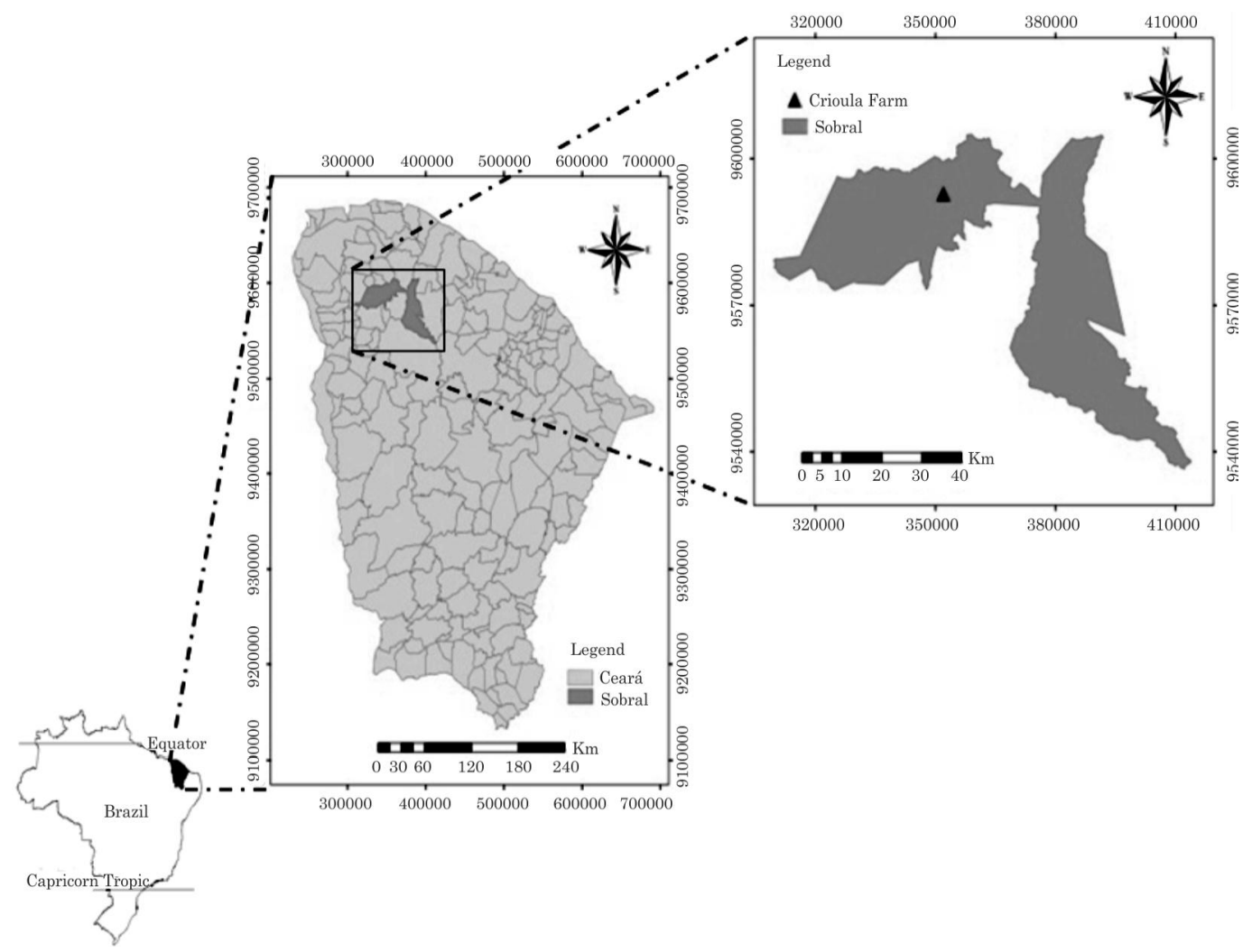

Figure 1. Location of the experimental area in the Crioula farm, Embrapa/CNPC, Sobral, Ceará, Brazil.

Table 1. Chemical and physical characterization in the 0-40 cm layer of typical Ortic Chromic Luvisol under natural vegetation and silvopastoral, agrosilvopastoral and traditional agricultural systems in Sobral, Ceará, Brazil

\begin{tabular}{|c|c|c|c|c|}
\hline \multirow{2}{*}{ Soil characteristic } & \multicolumn{4}{|c|}{ Management system } \\
\hline & Natural vegetation & Silvopastoral & Agrosilvopastoral & Traditional \\
\hline Coarse sand $\left(\mathrm{g} \mathrm{kg}^{-1}\right)^{(1)}$ & 321.6 & 461.6 & 265.7 & 308.6 \\
\hline Thin sand $\left(\mathrm{g} \mathrm{kg}^{-1}\right)^{(1)}$ & 233.3 & 216.2 & 364.7 & 293.1 \\
\hline Silt $\left(\mathrm{g} \mathrm{kg}^{-1}\right)^{(1)}$ & 276.7 & 208.8 & 255.7 & 236.9 \\
\hline Clay $\left(\mathrm{g} \mathrm{kg}^{-1}\right)^{(1)}$ & 168.4 & 113.4 & 113.9 & 164.4 \\
\hline Bulk density $\left(\mathrm{Mg} \mathrm{m}^{-3}\right)$ & 1.7 & 1.8 & 1.6 & 1.7 \\
\hline $\mathrm{pH}\left(\mathrm{H}_{2} \mathrm{O}\right)(1: 2.5)^{(1)}$ & 6.8 & 6.4 & 7.0 & 6.8 \\
\hline $\mathrm{Ca}^{2+}\left(\mathrm{cmol}_{\mathrm{c}} \mathrm{dm}^{-3}\right)^{(1)}$ & 22.1 & 6.3 & 21.8 & 16.9 \\
\hline $\mathrm{Mg}^{2+}\left(\mathrm{cmol}_{\mathrm{c}} \mathrm{dm}^{-3}\right)^{(1)}$ & 9.7 & 3.0 & 4.3 & 5.5 \\
\hline $\mathrm{K}^{+}\left(\mathrm{cmol}_{\mathrm{c}} \mathrm{dm}^{-3}\right)^{(1)}$ & 1.3 & 0.9 & 0.9 & 1.2 \\
\hline $\mathrm{Na}^{+}\left(\mathrm{cmol}_{\mathrm{c}} \mathrm{dm}^{-3}\right)^{(1)}$ & 0.2 & 0.1 & 0.2 & 0.2 \\
\hline $\operatorname{CEC}\left(\mathrm{cmol}_{\mathrm{c}} \mathrm{dm}^{-3}\right)^{(1)}$ & 35.6 & 12.7 & 28.0 & 26.1 \\
\hline Total organic carbon $\left(\mathrm{g} \mathrm{kg}^{-1}\right)$ & 23.5 & 16.4 & 13.6 & 10.8 \\
\hline Total nitrogen $\left(\mathrm{g} \mathrm{kg}^{-1}\right)$ & 1.1 & 0.9 & 0.9 & 0.6 \\
\hline
\end{tabular}

(1) Adapted from Maia et al. (2007). CEC: Cation-Exchange Capacity. 
Table 2. Description of the use and management of the experimental areas set in typical Ortic Chromic Luvisol in Sobral, Ceará, Brazil

\begin{tabular}{|c|c|c|c|}
\hline $\begin{array}{c}\text { Experimental } \\
\operatorname{area}^{(1)}\end{array}$ & $\begin{array}{l}\text { Management } \\
\text { system }\end{array}$ & $\begin{array}{l}\text { Dominant } \\
\text { tree family }\end{array}$ & $\begin{array}{l}\text { Soil history } \\
\text { and use }\end{array}$ \\
\hline $\begin{array}{l}\text { Native vegetation } \\
\qquad(3.1 \mathrm{ha})\end{array}$ & $\begin{array}{l}\text { Native vegetation } \\
\text { (Caatinga) } \\
\text { consisting of small } \\
\text { deciduous trees. }\end{array}$ & $\begin{array}{l}\text { Borragonaceae, } \\
\text { Euforbiaceae, } \\
\text { Caesalpinaceae, } \\
\text { Papilionaceae, } \\
\text { Combretaceae, } \\
\text { Mimosoideae and others } \\
\text { with limited abundance }\end{array}$ & $\begin{array}{l}\text { The Caatinga area, } \\
\text { where trees were } \\
\text { eliminated in 1981, } \\
\text { subsequently left in fallow } \\
\text { and occasionally used for } \\
\text { grazing in times of } \\
\text { severe drought. }\end{array}$ \\
\hline $\begin{array}{l}\text { Silvopastoral } \\
\qquad(4.8 \mathrm{ha})\end{array}$ & $\begin{array}{l}\text { Pasture for } 20 \text { sheep } \\
\text { during the dry and. } \\
\text { wet seasons }\end{array}$ & $\begin{array}{l}\text { Borragonaceae, } \\
\text { Mimosoideae and others } \\
\text { with limited abundance }\end{array}$ & $\begin{array}{l}\text { Deforestation reduced the } \\
\text { tree cover to } 260 \text { trees } \text { ha }^{-1} \\
\text { ( } 38 \% \text { ground cover). } \\
\text { After using the marketable } \\
\text { wood on the property, the } \\
\text { remaining timber was tied } \\
\text { in perpendicular bundles with } \\
\text { 0.4-m-wide cords. No tillage } \\
\text { or organic or chemical manures } \\
\text { were used in this area. }\end{array}$ \\
\hline $\begin{array}{l}\text { Agrosilvopastoral } \\
\qquad(1.6 \mathrm{ha})\end{array}$ & $\begin{array}{l}\text { Rows of Leucoena } s p . \\
\text { planted } \\
\text { every } 3.0 \mathrm{~m} \text {, with } \\
\text { maize (Zea mays L.) } \\
\text { between the rows in the } \\
\text { rainy season. Crop } \\
\text { residue grazing by } 20 \\
\text { sheep (Ovis aries) for } \\
1 \mathrm{~h}^{-1} \text { in the dry season. }\end{array}$ & $\begin{array}{l}\text { Borragonaceae, } \\
\text { Caesalpinaceae and } \\
\text { others with limited } \\
\text { abundance }\end{array}$ & $\begin{array}{l}\text { The tree cover of the area was } \\
\text { reduced to } 200 \text { trees ha }{ }^{-1} \text { ( } 22 \% \\
\text { ground cover) and the } \\
\text { remaining timber was tied in } \\
\text { bundles perpendicular to the } \\
\text { predominant landform in the } \\
\text { area. In the first three years, } \\
\text { the soil was tilled using a hoe } \\
\text { and then an animal-drawn } \\
\text { cultivator, for both planting } \\
\text { and weeding. The manure } \\
\text { produced by the sheep herd } \\
\text { was re-applied as fertilizer } \\
\text { to the area. }\end{array}$ \\
\hline $\begin{array}{l}\text { Traditional } \\
\text { (1.6 ha) }\end{array}$ & $\begin{array}{l}\text { Area left fallow after maize } \\
\text { (Zea mays L.) cultivation, } \\
\text { with } 0.3-0.5-\mathrm{m} \text { spacing } \\
\text { in } 2002 \text { and } 2003 \text { in the } \\
\text { rainy season; then left } \\
\text { fallow, after having been } \\
\text { used for grazing of crop } \\
\text { residues in the dry season. }\end{array}$ & $\begin{array}{l}\text { Hyptissuaveolens Poit, } \\
\text { Senna sp. and } \\
\text { Stylosanthes humilis H. B. K. } \\
\text { occur in the first fallow } \\
\text { years; subsequently, Croton } \\
\text { sonderianus Muell, } \\
\text { Caesalpinia brocteosa Tul, } \\
\text { Mimosa tenuiflora (Willd.) } \\
\text { Poir, Auxemma oncocalyx } \\
\text { Taub. and Combretum } \\
\text { leprosum Mart. }\end{array}$ & $\begin{array}{l}\text { Completely eliminated } \\
\text { Caatinga vegetation and } \\
\text { burned crop residues; the soil } \\
\text { was manually prepared with } \\
\text { a hoe and no mineral or } \\
\text { organic fertilization was } \\
\text { added. }\end{array}$ \\
\hline
\end{tabular}

(1) Adapted from Silva et al. (2011).

were $4.3,5.1$ and $49.9 \%$ in the SILV, AGP and TR systems, respectively.

The highest TOC levels were found in the NV system, followed by SILV, AGP and TR; TOC levels in the SILV, AGP and TR systems were not significantly different in the $40-60 \mathrm{~cm}$ layer. In the
TR, AGP and SILV systems, the TOC levels were, respectively 51,41 and $29 \%$ of the levels in the $0-60$ $\mathrm{cm}$ layer of the NV system (Figure 2). This large reduction in TOC levels under TR might be explained by the low organic material input, high tillage and routine crop residue burning, promoting the loss of 


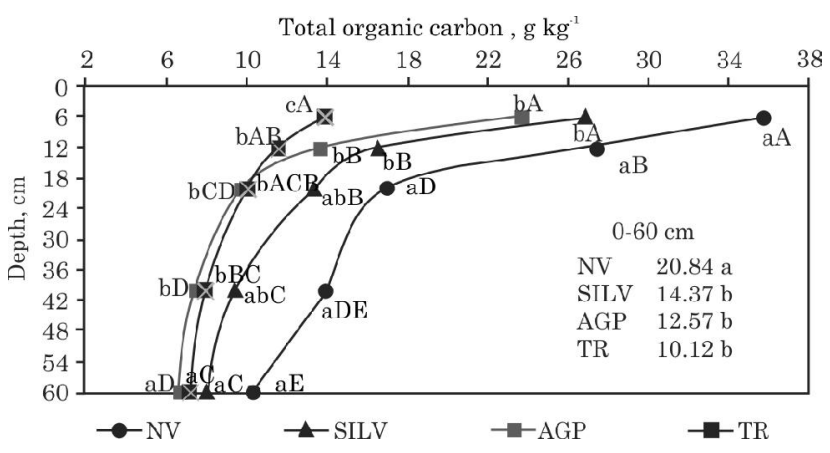

Figure 2. Soil total organic $C$ contents in a typical Ortic Chromic Luvisol under natural vegetation (NV) and silvopastoral (SILV), agrosilvopastoral (AGP) and traditional agricultural (TR) systems after 13 years of soil cultivation in Sobral-CE. Means followed by the same letters do not differ by Tukey's test at $5 \%$; uppercase letters compare soil depths in each management system and lowercase letters compare the management systems in each layer soil depth separately. The values in the figure represent the mean levels at all depths in each system.

organic matter. The reduction under AGP could be explained by tillage-induced organic matter oxidation and organic residue export from the system when all aerial parts of the annual crops were harvested for hay (to be used in the dry season) (Table 1); this reduction was observed even when the organic residues were replenished with manure from the sheep herd. The above reasons were corroborated by the results of Maia et al. (2006). In general, systems that prioritize tillage stimulate the action of microorganisms on organic compounds; indeed, these systems result in greater organic matter exposure, greater soil contact with plant debris and soil aggregate breakdown, which exposes the labile organic matter to oxidation (Costa et al., 2008). In the SILV system, lower amounts of organic material were added to the soil because the vegetation is used for animal grazing; therefore, no additional residues produced by animals were applied in this area.

These results clearly indicate that any tillage, regardless of intensity, promotes reduced soil TOC levels (Figure 2) (Maia et al., 2007, 2008; Veum et al., 2011; Novara et al., 2012); this is most likely due to an increased rate of organic matter decomposition (Novara et al., 2012). The landform can aggravate these disturbances and maximize the effects of the different studied management systems. The redistribution of water on the soil surface by runoff can create zones of accumulation (concave) and non-accumulation (convex); this in turn may affect different soil properties, including SOM. The conditions associated with these microclimates can alter the response capacity of the soil to several factors, e.g., the carbon sequestration capacity (Senthilkumar et al., 2009).
In contrast to AGP and SILV, in the systems with maximal (TR) and minimal (NV) soil use, no significant differences were found in TOC levels among the concave, convex and plain landforms (Table 3). Topsoil tillage at planting and/or the reduction in plant cover caused changes in the concave landforms, especially at the higher levels in the plain landforms under SILV and in the concave landforms under AGP. Differences between AGP and SILV highlight the effects of the landform and the regions of accumulation and topsoil movement. Interestingly, similar TOC levels were observed in the TR and AGP systems, demonstrating how runoff-promoted soil transport and accumulation can cause reduce the TOC levels with increasing intensity of soil use ( $\mathrm{TR}>\mathrm{AGP}>\mathrm{SILV}>\mathrm{NV})$.

The TOC stocks (Figure 3) were similar in the different layers (Figure 2), albeit with a marked increase between 20 and $60 \mathrm{~cm}$ deep. This increase was initially attributed to differences in the soil densities $(p<0.05$, Table 4$)$ between the different types of use, indicating a correlation between soil depth and TOC levels, especially at 10 and $20 \mathrm{~cm}$ or the third and fourth sampled layers. It should also be noted that these same layers had higher TOC levels and stocks in TR than in AGP, though these differences were not significant. This observation can be attributed to TR tillage and the movement of organic material from the surface to the subsurface.

The lowest TOC stock values were found in convex landforms under TR (71 $\left.\mathrm{Mg} \mathrm{ha}{ }^{-1}\right)$, whereas the highest values occurred in convex landforms under $\mathrm{NV}\left(179 \mathrm{Mg} \mathrm{ha}^{-1}\right)$. Intermediate stock TOC values of $171,153,142$ and $129 \mathrm{Mg} \mathrm{ha}^{-1}$ were found in concave and plain landforms under $\mathrm{NV}$, in plain landforms under SILV and in concave landforms under AGP, respectively (Figure 5).

According to Soto-Pinto et al. (2010), the C-stocking potential of AFSs in tropical regions ranges from 12 to $228 \mathrm{Mg} \mathrm{ha}^{-1}$ with an average of $95 \mathrm{Mg} \mathrm{ha}^{-1}$ at a depth of $100 \mathrm{~cm}$. In this study, the highest values always exceeded this average, thus demonstrating the C-stocking potential of these systems, especially because the maximum soil profile depth was $60 \mathrm{~cm}$ (typical for Luvisols according to Aguiar et al. (2006)). Even in the soil use systems and landforms with lower TOC stocks (convex landforms in TR and AGP systems, which had 60.4 and $59.0 \%$ less TOC than the NN+CV system, respectively), the 71.3 and 73.0 $\mathrm{Mg} \mathrm{ha}^{-1}$ stocks measured in these systems were still within the range of the TOC-stock potential of AFSs that were reported by Soto-Pinto et al. (2010).

The TOC stocks in the 0-40 layer (regardless of landform) in the TR, SILV and AGP systems were $58.87,23.87$ and $8.13 \mathrm{Mg} \mathrm{ha}^{-1}$ lower, respectively, than in 2002 when the same layers were assessed by Maia et al. (2007) (Table 5). On the other hand, TOC stocks increased by $9.6 \mathrm{Mg} \mathrm{ha}^{-1}$ in NV. These results may be associated with the season in which the samples were collected; Maia et al. (2007) collected samples four 
years after initiating the experiment (1998), when the residues generated by tree thinning in the system were applied to the soil, which partly affected the initial stocks. The natural biomass reduction in 2011 may have been due to the removal of residues from the aerial parts of trees outside the area where the thinning was performed, as well as the decomposition of organic residues that were placed on the topsoil at

Table 3. Total organic $\mathrm{C}$ and total $\mathrm{N}$ contents in a typical Ortic Chromic Luvisol under natural vegetation and silvopastoral, agrosilvopastoral and traditional agricultural systems in the plain, convex and concave landforms after 13 years of cultivation in Sobral, Ceará, Brazil

\begin{tabular}{|c|c|c|c|c|c|c|}
\hline \multirow{3}{*}{ Management system } & \multicolumn{3}{|c|}{ Total organic C } & \multicolumn{3}{|c|}{ Total N } \\
\hline & \multicolumn{6}{|c|}{ Landform } \\
\hline & Plain & Convex & Concave & Plain & Convex & Concave \\
\hline & & & $-\mathrm{g}$ & & & \\
\hline Natural vegetation & $19.46 \mathrm{aA}$ & $22.87 \mathrm{aA}$ & $20.18 \mathrm{aA}$ & $0.88 \mathrm{aAB}$ & $0.82 \mathrm{aB}$ & $1.06 \mathrm{aA}$ \\
\hline Silvopastoral & $17.24 \mathrm{abA}$ & $14.05 \mathrm{bAB}$ & $12.90 \mathrm{bB}$ & $0.87 \mathrm{aA}$ & $0.73 \mathrm{abA}$ & $0.87 \mathrm{aA}$ \\
\hline Agrosilvopastoral & $10.81 \mathrm{cB}$ & $10.24 \mathrm{bB}$ & $15.71 \mathrm{abA}$ & $0.57 \mathrm{bB}$ & $0.80 \mathrm{aAB}$ & $0.96 \mathrm{aA}$ \\
\hline Traditional farming & $11.19 \mathrm{bcA}$ & $8.11 \mathrm{bA}$ & $11.06 \mathrm{bA}$ & $0.53 \mathrm{bA}$ & $0.53 \mathrm{bA}$ & $0.55 \mathrm{bA}$ \\
\hline
\end{tabular}

Means followed by the same letter do not differ by Tukey's test at $5 \%$; uppercase letters compare the landforms and lowercase letters the management systems.

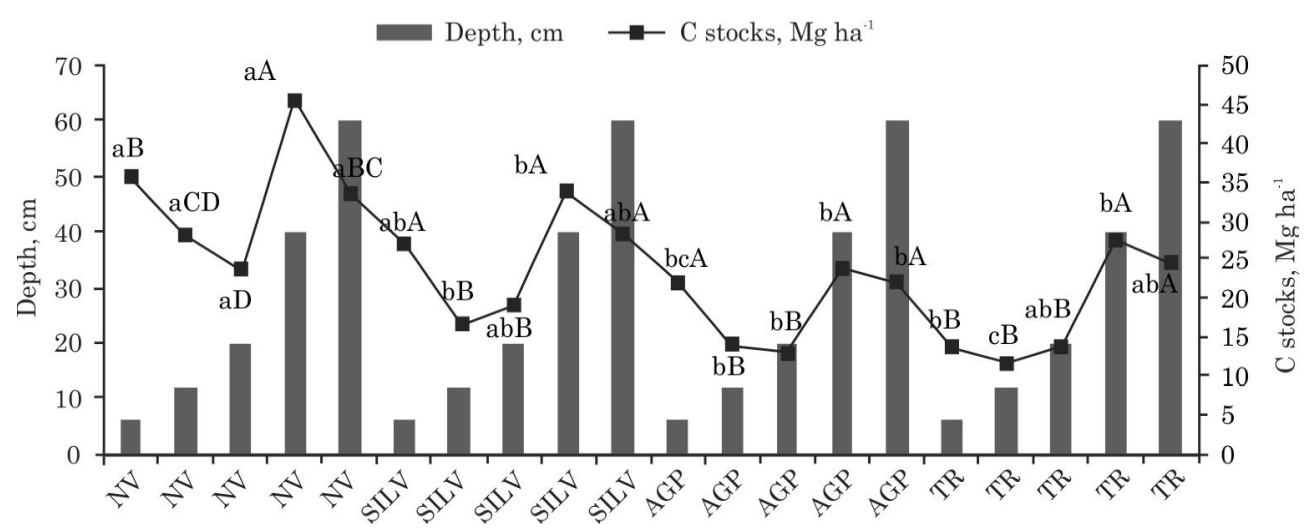

Figure 3. Soil total organic C (TOC) stocks in a typical Ortic Chromic Luvisol under natural vegetation (NV) and silvopastoral (SILV), agrosilvopastoral (AGP) and traditional agricultural (TR) systems after 13 years of cultivation in Sobral, Ceará. Means followed by similar letters do not differ by Tukey's test at $5 \%$; uppercase letters compare the layers in each area and lowercase letters the areas in each layer.

Table 4. Values of bulk density in different soil dephts in a typical Ortic Chromic Luvisol under natural vegetation and silvopastoral, agrosilvopastoral and traditional agricultural systems after 13 years of use in Sobral, Ceará, Brazil

\begin{tabular}{lccccc}
\hline \multirow{2}{*}{ Management system } & \multicolumn{5}{c}{ Depth (cm) } \\
\cline { 2 - 6 } & $\mathbf{0 - 6}$ & $\mathbf{6 - 1 2}$ & $\mathbf{1 2 - 2 0}$ & $\mathbf{2 0 - 4 0}$ & $\mathbf{4 0 - 6 0}$ \\
\cline { 2 - 6 } & & & Mg m & \\
Natural vegetation & $1.67 \mathrm{aA}$ & $1.74 \mathrm{aA}$ & $1.77 \mathrm{aA}$ & $1.66 \mathrm{bcA}$ & $1.65 \mathrm{Ba}$ \\
Silvopastoral & $1.69 \mathrm{aB}$ & $1.75 \mathrm{aAB}$ & $1.81 \mathrm{aAB}$ & $1.82 \mathrm{aA}$ & $1.79 \mathrm{aAB}$ \\
Agrosilvopastoral & $1.57 \mathrm{aA}$ & $1.69 \mathrm{aA}$ & $1.68 \mathrm{aA}$ & $1.62 \mathrm{cA}$ & $1.62 \mathrm{bA}$ \\
Traditional farming & $1.66 \mathrm{aA}$ & $1.75 \mathrm{aA}$ & $1.78 \mathrm{aA}$ & $1.76 \mathrm{abA}$ & $1.70 \mathrm{abA}$ \\
\hline
\end{tabular}

Means followed by the same letter do not differ by Tukey's test at $5 \%$; uppercase letters compare the differences among soil dephts and lowercase letters the differences among management systems. 


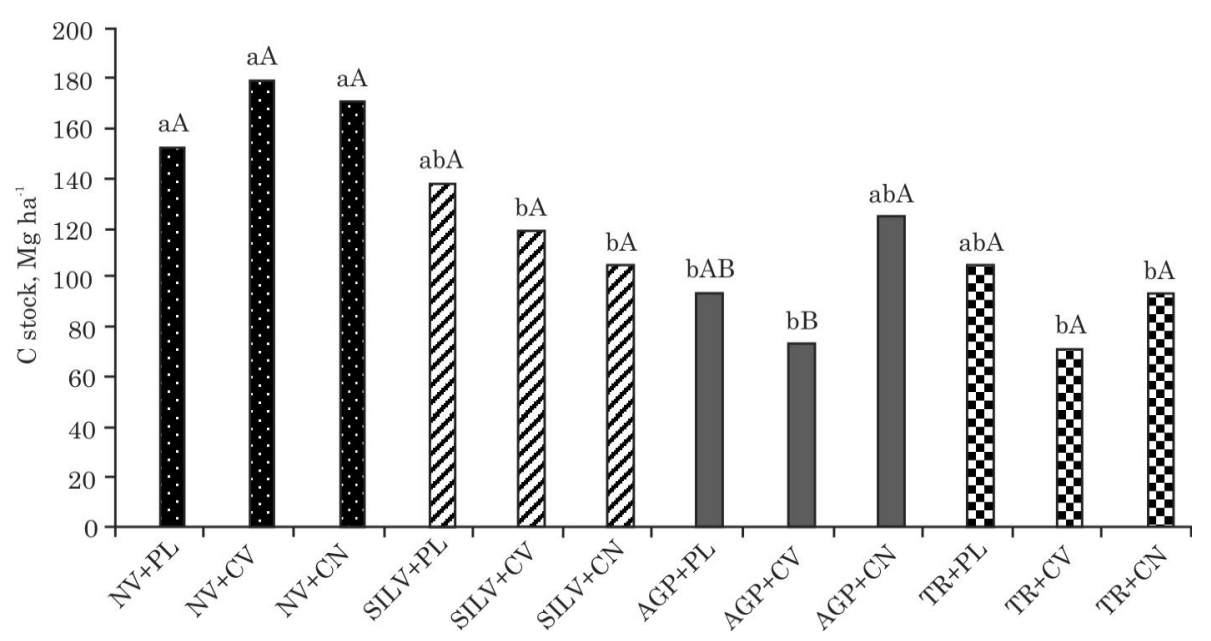

Figure 4. Soil TOC stocks in the 0-60-cm layer in a typical Ortic Chromic Luvisol under natural vegetation (NV) and silvopastoral (SILV), agrosilvopastoral (AGP) and traditional agricultural (TR) systems in plain (PL), convex (CV) and concave (CN) landforms after using Luvisol for 13 years in Sobral, Ceará. Means followed by similar letters do not differ by Tukey's test at $5 \%$; uppercase letters compare the landforms in each area and lowercase letters compare the areas in each landform.

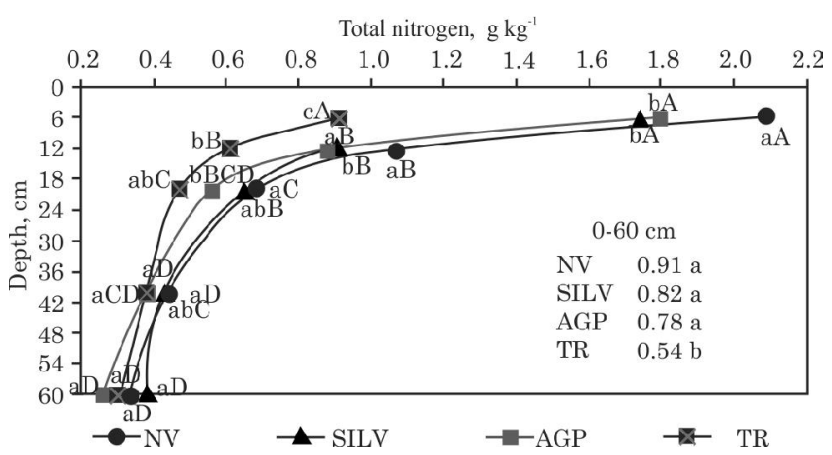

Figure 5. Total $N$ contents in a typical ortic Chromic Luvisol under natural vegetation (NV) and silvopastoral (SILV), agrosilvopastoral (AGP) and traditional agricultural (TR) systems after 13 years of soil cultivation in Sobral-CE. Means followed by the same letters do not differ by Tukey's test at $5 \%$; uppercase letters compare soil depths in each management system and lowercase letters compare the management systems in each layer soil depth separately. The values in the figure represent the mean levels at all depths in each system.

the beginning of the AGP and SILV experiments. It is noteworthy that in TR systems, where fire is used, this reduction in residues from the aerial parts of trees was immediate. Part of the organic residues in systems other than TR might result from interactions between the soil mineral fraction and structural protection (Huang, 2004). The losses in AGP were minimized by the input of organic residues generated by the sheep herd. In fact, in the AGP system, the TOC stocks did not decrease even after topsoil tilling. In a study conducted in the Mediterranean semiarid region,
Novara et al. (2012) noted a reduction of $58 \mathrm{Mg} \mathrm{ha}^{-1}$ in $\mathrm{C}$ in the $0-40-\mathrm{cm}$ layer at sites that had been converted from native vegetation to agriculture; however, tillage had been performed with plows and moldboards for 36 years, which is 23 years longer than the cultivation period in this study.

\section{Total soil nitrogen levels and stocks}

Total N levels (TN) showed similar trends as the TOC levels as was previously reported in the literature (Longo \& Espíndola, 2000). The TN levels in all treatments were higher in the topsoil layers (0-6, 6-12 and $12-20 \mathrm{~cm}$ ) and decreased significantly with increasing depth (Figure 5). No statistically significant differences in $\mathrm{TN}$ were found between the systems, and the $\mathrm{TN}$ levels remained constant in the deepest layers (20-40 and 40-60 cm). Differences in TN in the topsoil layers were found between management systems, where the highest TN levels were observed under NV, followed by AGP, SILV, and TR. Respectively, the TN levels in the TR, AGP and SIL systems were 56, 13.9 and $15.8 \%$ of the levels under $\mathrm{NV}$ at $0-6 \mathrm{~cm} ; 42.2,16.8$ and $14.9 \%$ of the NV levels at $6-12 \mathrm{~cm}$; and $30.8,16.2$ and $4.4 \%$ of the NV levels at $12-20 \mathrm{~cm}$ (Figure 6 ).

Maia et al. (2008) found TN levels of 5.46 and $3.02 \mathrm{~g} \mathrm{~kg}^{-1}$ in the $0-6$ and $6-12$-cm layers in the same experimental area, respectively, and attributed these high values to the higher soil clay content and the effect of organic matter on the topsoil, thus demonstrating the relationship between the organic and mineral soil fractions. Significant TN losses were observed in the TR agricultural system over time; the TN levels were 83.3 and $79.8 \%$ lower in 2011 than they were in 2002. Reductions under the TR system could be related to topsoil tillage (wherein cultivators and hoes were used to weed and open pits), 
Table 5. Total organic C and total N stocks in 2002 and 2011 in a typical Ortic Chromic Luvisol under natural vegetation (NV) and silvopastoral (SILV), agrosilvopastoral (AGP) and traditional agricultural (TR) systems in the 0-40 cm layer in Sobral, Ceará

\begin{tabular}{|c|c|c|c|c|c|c|}
\hline \multirow{2}{*}{ Management system } & \multicolumn{3}{|c|}{ Total organic $\mathrm{C}$ stock } & \multicolumn{3}{|c|}{ Total nitrogen stock } \\
\hline & $2002^{(1)}$ & 2011 & Difference & $2002^{(1)}$ & 2011 & Difference \\
\hline & & & $-\mathrm{Mg}$ & & & \\
\hline Natural vegetation & 125.05 & 134.65 & 9.6 & 10.15 & 5.65 & -4.5 \\
\hline Silvopastoral & 121.46 & 97.59 & -23.87 & 10.56 & 5.23 & -5.33 \\
\hline Agrosilvopastoral & 76.77 & 71.64 & -8.13 & 8.53 & 4.09 & -4.44 \\
\hline Traditional farming & 127.03 & 68.16 & -58.87 & 13.16 & 3.59 & -9.57 \\
\hline
\end{tabular}

(1) Source: Maia et al. (2007).

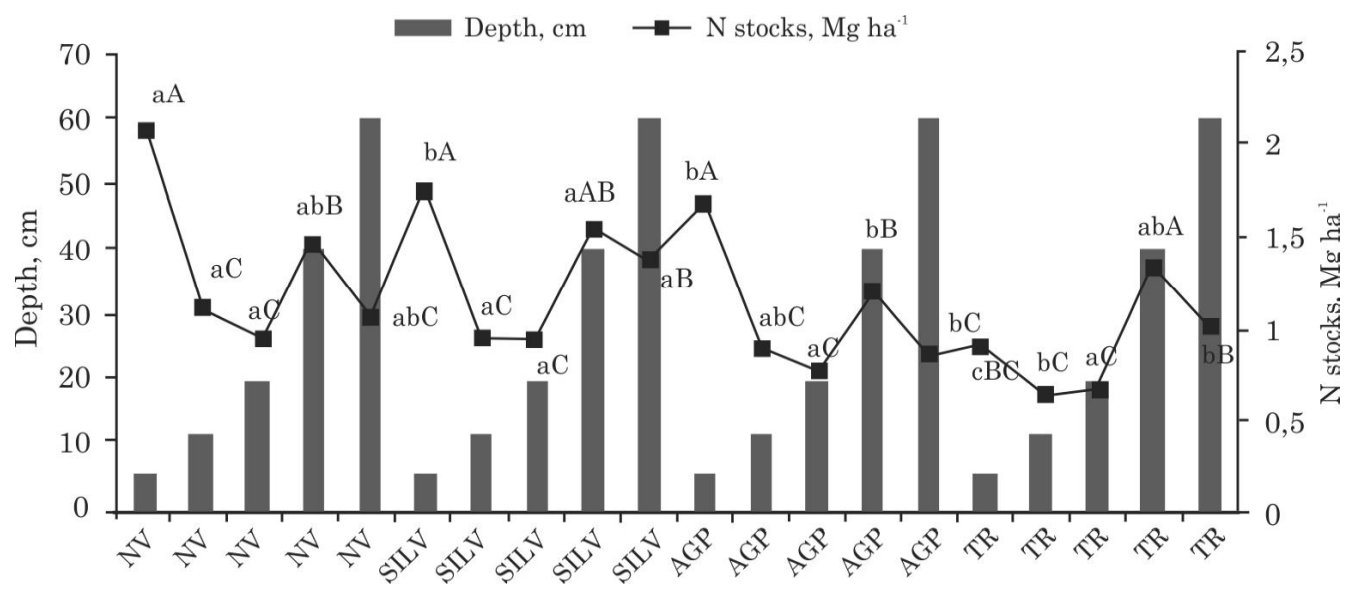

Figure 6. Soil total N (TN) stocks in a typical Ortic Chromic Luvisol under natural vegetation (NV) and silvopastoral (SILV), agrosilvopastoral (AGP) and traditional agricultural (TR) systems after 13 years of soil cultivation in Sobral, Ceará. Means followed by similar letters do not differ by Tukey's test at $5 \%$; uppercase letters compare the layers in each area and lowercase letters compare the areas in each layer.

slash-and-burn methods, to a lack of input of organic material and to increased topsoil exposure, favoring SOM mineralization.

Reductions in TN levels were also reported by Heinze et al. (2010) in a long-term experiment in Luvisol in Germany to evaluate the use of a disc harrow; these authors reported TN levels that were $22 \%$ lower than those found in the topsoil layers of a system with minimum tillage. This decrease was related to soil aggregate breakdowns, which change the soil temperature and water content, thus promoting denitrification. According to PerroniVentura et al. (2010), N limitations in arid and semiarid ecosystems are aggravated by soil losses due to erosion, leaching, ammonia volatilization and denitrification processes.

The variability in the TN levels among the systems indicated the occurrence of TN losses or gains. The SILV, AGP and TR levels were 10.8, 15.2 and $41.3 \%$ lower than the NV levels, respectively. However, the SILV and AGP levels were 34.1 and $30.7 \%$ higher than the TR levels, thus demonstrating the efficacy of AFSs in TN preservation.

For all treatments, the highest TN levels were found in the concave landform, followed by the plain and convex landforms; the highest TN levels were observed under NV, followed by the AGP and SILV systems (Table 3 ). These results confirm the hypothesis that the concave landform enables organic material accumulation in the soil (Bergstrom et al., 2001), leading to increased N levels.

The convex and plain landforms had the lowest TN values (Table 3). At locations where the rainfall intensity in a short time period is very high (as in semiarid regions), the terrain has a significant effect on water dynamics because it directly affects the water erosion process (Zygmunt, 2009). Accordingly, the convex landform is mainly responsible for accelerating topsoil runoff. Consequently, much of the A horizon, which consists of sandy soil that is rich in organic matter and nutrients (typical of Luvisols), is carried away, thus exposing the 
hardened, mostly clay, Bt horizon. This condition aggravates erosion processes, especially in regions where tillage is performed. In convex landforms, the TN levels in the TR system were $35.3 \%$ lower than under NV.

Similar trends were observed for TOC, including the increase in TOC levels between 20 and $60 \mathrm{~cm}$ deep. This increase was associated with the depths used in the calculations and not necessarily with differences in the soil density, as found during assessments of the TN stocks in the different layers (Figure 6). The highest TN stocks were found in the concave landforms $(\mathrm{CN})$ in all areas, and the highest values were found in the NV, AGP and SILV systems. The $\mathrm{TN}$ stocks were lowest in the $\mathrm{TR}+\mathrm{CN}$ soils, and these stocks were significantly different from those found in the other systems (Figure 7). In the $\mathrm{TR}+\mathrm{CN}$ system, the total $\mathrm{N}$ stocks were 42,34 and $30 \%$ of the levels found in the $\mathrm{NV}+\mathrm{CN}, \mathrm{AGP}+\mathrm{CN}$ and SILV+CN systems, respectively.

Studies of other traditional management systems have reported higher TN stock values (D'Andréa et al., 2004; Lovato et al., 2004; Leite et al., 2009) than those found in this study. This discrepancy could be due to the use of mineral fertilization, improving the plant development and consequently increasing residue inputs into the soil. The traditional system, on the other hand, does not apply any type of mineral fertilization. The lack of mineral fertilization, the low organic residue supply, the nutrient export that occurs with the harvest, the burning of crop residues and tillage with cultivators and hoes in the TR system are most likely responsible for the low TN stock values observed in this system. In contrast, the stock values in AGP and SILV did not differ from those under NV. Few reliable datasets are available for the effects of agroforestry systems on TN stocks (Mao et al., 2010).
Some authors observed increases in TN stocks after the conversion of land into agroforestry systems (Sartori et al., 2007; Morris et al., 2007), while others reported decreases in TN stocks upon conversion (Smal \& Olszewska, 2008). The low TN stocks could be related to low plant residue input, the accumulation of the aerial parts of plants and the lack of $\mathrm{N}$ fertilization, while the high stocks could be related to plant residue sedimentation and atmospheric N (Mao et al., 2010).

In TR systems in the 0-40 cm layer (regardless of landform), the TN stocks were $9.57 \mathrm{Mg} \mathrm{ha}^{-1}$ lower in 2011 than those from 2002 (Table 5). Losses in the SILV and AGP systems over time were lower (respective reductions of 5.33 and $4.44 \mathrm{Mg} \mathrm{ha}^{-1}$ ). In TR systems, TN may be lost by nitrate leaching or by $\mathrm{NH}_{3}$ volatilization or denitrification due to tillageinduced MOS mineralization in unprotected soils. Indeed, tillage promotes soil disaggregation, leading to SOM exposure and favoring biological oxidation, increased aeration and increased soil temperature, all of which can increase the processes of denitrification and ammonification (Sisti et al., 2004).

\section{CONCLUSIONS}

1. Of the agroforestry systems studied, reductions in $\mathrm{C}$ and $\mathrm{N}$ stocks after 13 years were greatest in the silvopastoral system, while $\mathrm{C}$ and $\mathrm{N}$ losses were lowest in the agrosilvopastoral system. Thus, the AGP system seems promising as a way of promoting soil sequestration of $\mathrm{C}$ and $\mathrm{N}$ under the conditions in the semi-arid region of Brazil.

2. The traditional agricultural system led to substancial reductions of TOC and TN stocks,

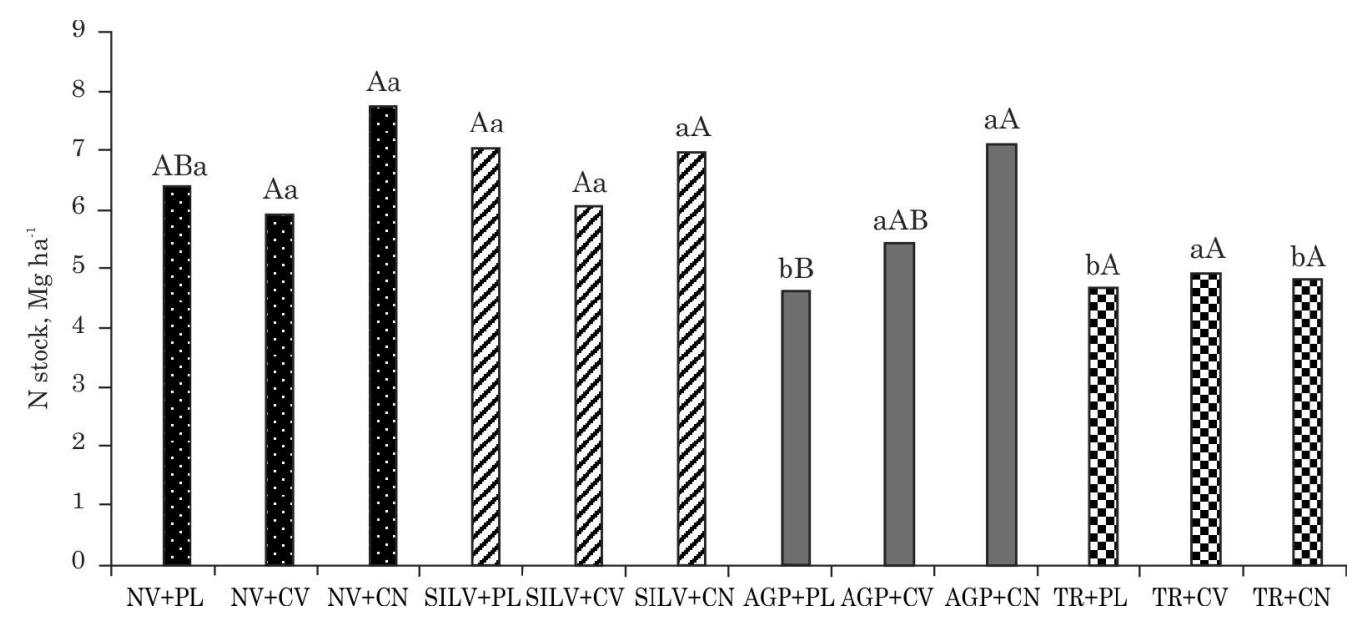

Figure 7. Soil total N (NT) stocks in the 0-60-cm layer of a typical Ortic Chromic Luvisol under natural vegetation (NV) and silvopastoral (SILV), agrosilvopastoral (AGP) and traditional agricultural (TR) systems under plain (PL), convex (CV) and concave (CN) landforms after 13 years of cultivation in Luvisol in Sobral-CE. Means followed by similar letters do not differ by Tukey's test at $5 \%$; uppercase letters compare the landforms in each area and lowercase letters compare the areas in each landform. 
indicating that this system is inadequate for Brazilian semiarid conditions.

3. The concave and plain landforms presented the highest organic $\mathrm{C}$ stocks, whereas highest $\mathrm{N}$ stocks were registered in concave landform in all management systems evaluated.

\section{ACKNOWLEDGEMENTS}

The authors wish to thank Francisco Éden Paiva Fernandes, a researcher at Embrapa/CNPC, for his help with this study and the National Council for Scientific and Technological Development (CNPq) and the Brazilian Federal Agency for Support and Evaluation of Graduate Education (CAPES) for funding this research and granting scholarships to the authors.

\section{LITERATURE CITED}

AGUIAR, M.I.; MAIA, S.M.F.; OLIVEIRA, T.S.; MENDONÇA, E.S. \& ARAÚJO FILHO, J.A. Perdas de solo, água e nutrientes em sistemas agroflorestais no município de Sobral, CE. R. Ci. Agron., 37:270-278, 2006.

AGUIAR, M.I.; MAIA, S.M.F.; XAVIER, F.A.S.; MENDONÇA, E.S.; ARAÚJO FILHO, J.A. \& OLIVEIRA, T.S. Sediment, nutrient and water losses by water erosion under agroforestry systems in the semi-arid region in northeastern Brazil. Agrofor. Syst., 79:277-289, 2010.

ARAÚJO FILHO, J.A. Caatinga: Agroecologia versus desertificação. Ci. Hoje, 30:44-45, 2002.

BERGSTROM, D.W.; MONREAL, C.M. \& JACQUES, E.S.T. Spatial dependence of soil organic carbon mass and its relationship to soil series and topography. Can. J. Soil Sci., 81:53-62, 2001.

BORTOLON, E.S.O.; MIELNICZUK, J.; TORNQUIST, C.G.; LOPES, F. \& FERNANDES, F.F. Simulação da dinâmica do carbono e nitrogênio em um Argissolo do Rio Grande do Sul usando modelo Century. R. Bras. Ci. Solo, 33:1635-1646, 2009.

BREMNER, J.M. Nitrogen total. In: SPARKS, D.L., ed. Methods of soil analysis. Madison, American Society of Agronomy, 1996. Part 3. p.1085-1121 (SSSA Book Series, 5)

CERRI, C.E.P.; FEIGL, B. \& CERRI, C.C. Dinâmica da matéria orgânica do solo na Amazônia. In: SANTOS, G.A.; SILVA, L.S.; CANELLAS, L.P. \& CAMARGO, F.O., eds. Fundamentos da matéria orgânica do solo: Ecossistemas tropicais e subtropicais. Porto Alegre, Gênesis, 2008. p.325-358.

COSTA, F.S.; ZANATTA, J.A. \& BAYER, C. Emissões de gases de efeito estufa em agroecossistemas e potencial de mitigação. In: SANTOS, G.A.; SILVA, L.S.; CANELLAS, L.P. \& CAMARGO, F.A.O., eds. Fundamentos da matéria orgânica do solo: Ecossistemas tropicais e subtropicais. Porto Alegre, Gênesis, 2008. p.545-559.
D'ANDRÉA, A.F.; SILVA, M.L.N.; CURI, N. \& GUILHERME, L.R.G. Estoque de carbono e nitrogênio mineral em um solo submetido a diferentes sistemas de manejo. Pesq. Agropec. Bras., 39:179-186, 2004.

EMPRESA BRASILEIRA DE PESQUISA AGROPECUÁRIA EMBRAPA. Manual de métodos de análises de solos. 2.ed. Rio de Janeiro, 1997. 212p.

EMPRESA BRASILEIRA DE PESQUISA AGROPECUÁRIA EMBRAPA. Sistema brasileiro de classificação de solos. 2.ed. Rio de Janeiro, 2006. 306p.

HEINZE, A.; RAUBER, R. \& JOERGENSEN, R.G. Influence of mouldboard plough and Rotary harrow tillage on microbial biomass and nutrient stocks in two long-term experiments on loess derived Luvissols. Appl. Soil Ecol., 46:405-412, 2010.

HUANG, P.M. Soil mineral - organic matter - microorganism interactions: Fundamentals and impacts. Adv. Agron., 82:391-472, 2004.

INDICADORES DE DESENVOLVIMENTO SUSTENTÁVEL: Brasil 2010. Rio de Janeiro, IBGE, 2010. 443p. (Estudos e Pesquisas. Informação Geográfica, 7)

INSTITUTO DE PESQUISA E ESTRATÉGIA ECONÔMICA DO CEARÁ - IPECE. Perfil Básico Municipal Sobral. Fortaleza, SEPLAN - Secretaria do Planejamento e Coordenação, Governo do Estado do Ceará, 2005.10p.

LEITE, L.F.C.; CARDOSO, M.J.; COSTA, D.B.; FREITAS, R.C.A.; RIBEIRO, V.Q. \& GALVÃO, S.R.S. Estoques de $\mathrm{C}$ e de $\mathrm{N}$ e produtividade do milho sob sistemas de preparo e adubação nitrogenada em um Latossolo VermelhoAmarelo do cerrado piauiense, Ci. Rural, 39:2460-2466, 2009.

LONGO, R.M. \& ESPÍNDOLA, C.R. C-orgânico, N-total e substâncias húmicas sob influência da introdução de pastagens (Brachiaria sp.) em áreas de Cerrado. R. Bras. Ci. Solo, 24:723-729, 2000.

LOVATO, T.; MIELNICZUK, J. \& VEZZANI, F. Adição de carbono e sua relação com os estoques no solo e com o rendimento do milho em sistemas de manejo. R. Bras. Ci. Solo, 28:175-187, 2004.

MAIA, S.M.F.; XAVIER, F.A.S.; OLIVEIRA, T.S.; MENDONÇA, E.S. \& ARAÚJO FILHO, J.A.; Impactos de sistemas agroflorestais e convencional sobre a qualidade de solo no semi-árido cearense. R. Árvore, 30:837-848, 2006.

MAIA, S.M.F.; XAVIER, F.A.S.; OLIVEIRA, T.S.; MENDONÇA, E.S. \& ARAÚJO FILHO, J.A. Organic carbon pools in a Luvisol under agroforestry an conventional farming systems in the semiarid region of Ceará, Brazil. Agrofor. Syst., 71:127-138, 2007.

MAIA, S.M.F.; XAVIER, F.A.S.; OLIVEIRA, T.S.; MENDONÇA, E.S. \& ARAÚJO FILHO, J.A. Frações de nitrogênio em Luvissolo sob sistemas agroflorestais e convencional no semiárido cearense. R. Bras. Ci. Solo, 32:381-392, 2008.

MAIA, S.M.F.; OGLE, S.M.; CERRI, C.E.P. \& CERRI, C.C. Changes in soil organic carbon storage under different agricultural management systems in the Southwest Amazon Region of Brazil. Soil Till. Res., 106:177-184, 2010. 
MAO, R.; ZENG, D.; HU, Y.; LI, L. \& YANG, D. Soil organic carbon and nitrogen stocks in an age-sequence of poplar stands planted on marginal agricultural land in Northeast China. Plant Soil, 332:277-287, 2010.

MORRIS S. J.; BOHM, S.; HAILE-MARIAM, S. \& PAUL, E. A.; Evaluation of carbon accrual in afforested agricultural soils. Global Change Biol., 13:1145-1156, 2007.

NOGUEIRA, R.S. Distribuição especial de carbono, nutrientes e solo em Luvissolo sob sistemas agrícolas tradicionais e agroflorestais no município de Sobral - CE. Fortaleza, Universidade Federal do Ceará, 2009. 138p. (Dissertação de Mestrado)

NOGUEIRA, R.S.; OLIVEIRA, T.S.; TEIXEIRA, A.S. \& ARAÚJO FILHO, J.A. Redistribuição de carbono orgânico e fósforo pelo escoamento superficial em sistemas agrícolas convencionais e agroflorestais no semi-árido cearense. R. Ceres, 55:327-337, 2008.

NOVARA, A.; LA MANTIA, T.; BARBERA, V. \& GRISTINA, L. Paired-site approach for studying soil organic carbon dynamics in a Mediterranean semiarid environment. Catena, 89:1-7, 2012.

NUNES, R.S.; LOPES, A.A.C.; SOUZA, D.M.G. \& MENDES, I.C. Sistemas de manejo e os estoques de carbono e nitrogênio em Latossolo de Cerrado com a sucessão sojamilho. R. Bras. Ci. Solo, 35:1407-1419, 2011.

PERRONI-VENTURA, Y.; MONTAÑA, C. \& GARCÍA-OLIVA, F. Carbon-nitrogen interactions in fertility island soil from a tropical semi-arid ecosystem. Func. Ecol., 24:233$242,2010$.

RANGEL, O.J.P \& SILVA, C.A. Estoques de carbono e nitrogênio e frações orgânicas de Latossolos submetidos a diferentes sistemas de uso e manejo. R. Bras. Ci. Solo, 31:1609-1623, 2007.

SARTORI, F.; LAL, R.; EBINGER, M.H. \& EATON, J.A. Changes in soil carbon and nutrient pools along a chronosequence of poplar plantations in the Columbia Plateau, Oregon, USA, Agric. Ecosyst. Environ., 122:325339, 2007.

SENTHILKUMAR, S.; KRAVCHENKO, A.N. \& ROBERSTON, G.P. Topography influences management system effects on total soil carbon and nitrogen. Soil Sci. Soc. Am. J., 73:2059-2067, 2009.

SHARMA, K.L.; MANDAL, U.K.; SRINIVAS, K.; VITTAL, K.P.R.; MANDAL, B.; GRACE, J.K. \& RAMESH, V. Longterm soil management effects on crop yields and soil quality in dryland Alfisol. Soil Till. Res., 83:246-259, 2005.
SILVA, F.A.S.E. \& AZEVEDO, C.A.V. Principal components analysis in the software Assistat-statistical attendance. In: WORLD CONGRESS ON COMPUTERS IN AGRICULTURE, 7., Reno, 2009. Proceedings... RenoNV-USA, American Society of Agricultural and Biological Engineers, 2009. Available at: <http://assistat.com>

SILVA, G.L.; LIMA, H.V.; CAMPANHA, M.M.; GILKES, R.J. \& OLIVEIRA, T.S. Soil physical quality of Luvisols under agroforestry, natural vegetation and conventional crop management systems in the Brazilian semi-arid region. Geoderma, 167/168:61-70, 2011.

SISTI, C.P.J.; SANTOS, H.P.; KOHHANN, R.; ALVES, B.J.R.; URQUIAGA, S. \& BODDEY, R.M. Change in carbon and nitrogen stocks in soil under 13 years of conventional or zero tillage in southern Brazil. Soil Till. Res., 76:39-58, 2004.

SMAL, H. \& OLSZEWSKA, M. The effect of afforestation with scots pine (Pinus silvestris L.) of sandy post-arable soils on their selected properties. II. Reaction, carbon, nitrogen and phosphorus. Plant Soil, 305:171-187, 2008.

SOTO-PINTO, L.; ANZUETO, M.; MENDOZA, J.; FERRER, G.J. \& JONG, B. Carbon sequestration through agroforestry in indigenous communities of Chiapas, México. Agrofor. Syst., 78:39-51, 2010.

SOUZA， E.D.; COSTA, S.E.V.G.A.; ANGHINONI， I.; CARVALHO, P.C.F.; ANDRIGUETI, M. \& CAO, E. Estoque de carbono orgânico e de nitrogênio no solo em sistemas de integração lavoura pecuária em plantio direto, submetido à intensidade de pastejo. R. Bras. Ci. Solo, 33:1829-1836, 2009.

TONUCCI, R.G.; NAIR, P.K.R.; NAIR, V.D.; GARCIA, R. \& BERNARDINO, F.S. Soil carbon storage in silvopasture and related land-use systems in the Brazilian Cerrado. J. Environ. Qual., 40:833-841, 2011.

VEUM, K. S.; GOYNE, K. W.; HOLAN, S. H. \& MOTAVALLI, P. P. Assessment of soil organic carbon an total nitrogen under conservation management practices in the Central Claypan Region, Missouri, USA. Geoderma, 167-168:188196, 2011.

YEOMANS, J.C. \& BREMNER, J.M. A rapid and precise method for routine determination of organic carbon in soil. Comnun. Soil Sci. Plant Anal., 19:1467-1476, 1988.

XAVIER, F.A.S.; MAIA, S.M.F.; OLIVEIRA, T.S. \& MENDONÇA, E.S. Biomassa e matéria orgânica leve em solos sob sistemas agrícolas orgânico e convencional na Chapada da Ibiapaba, CE. R. Bras. Ci. Solo, 30:247-258, 2006.

ZYGMUNT, E. Alluvial as an effect of long-term man-landscape interactions and climatic conditions: A case study from the Glubczyce Plateau, SW Poland. Geomorphology, 108:58-70, 2009. 